\title{
A Study on the Present Situation of College Students' Honesty and Credit and the Countermeasures
}

\author{
Guijuan $\mathrm{Qu}^{1,}$, , Shanghong Ding ${ }^{2, \mathrm{~b}}$ and Xiaoqing Dong ${ }^{1, c}$ \\ ${ }^{1}$ Jilin Agricultural University, College of animal science and technology, China \\ ${ }^{2}$ Jilin Teyan Biotechnological CoLLtd, Changchun 130122 \\ aquguijuan2003@sina.cn, b387867001@qq.com, cdxg200912@163.com
}

Keywords: College students; Integrity; Quality education; Measures

\begin{abstract}
Honesty is the traditional virtue of the Chinese nation Is the first of quality education. College students are the master of the future society, Should have the necessary integrity of quality. However, with the continuous development of social economy, The problem of college students' integrity is becoming more and more prominent. In this paper, the status quo of the current integrity of college students, the causes of the problems and solutions to be elaborated.
\end{abstract}

\section{Introduction}

Honesty is the traditional virtue of the Chinese nation, is the first of quality education. Honesty is of great significance to enhance the moral level of college students and the stability of the campus. However, in recent years, with the impact of reform and opening and the tide of market economy, the relationship between interests, interpersonal and personnel relations has become more and more complicated with the transition of macro system in China. In this environment, many college students have been bad influence, Integrity of the status quo worrying, which, we must pay great attention. In this paper, the status quo of the current integrity of college students, the causes of the problems and solutions to be elaborated.

\section{The Status Quo of College Students Integrity}

Cheating is Serious and Repeated. The integrity of college students is mainly reflected in the study, the most prominent is the rise of various fraud, for example, in the course of the final exam, often appear cheating [1-2]. Cheating a variety of means, mixed notes, cell phone text messages, pasting the notes on the mineral water bottles, writing words on the wall and the desktop and so on. In the process of writing undergraduate thesis, plagiarism papers, changing data and other phenomena have occurred. In addition, some of the major examinations in the country, there are still some students willing to risk to cheat through various means, and repeated prohibitions.

Student Loans do not Keep Faith, Return also do not Return. Student loans is a national policy of benefiting the people, mainly the use of financial means to help the students with family financial difficulties to complete their studies, for the country to cultivate more talent. However, some college students lack the correct understanding of integrity, due to their various objective reasons, the phenomenon of default repayment is getting more and more serious, and even a small number of loan students after graduation cut off all contact with the loan bank, graduation school and the relevant departments and other extreme behavior [3]. This happens, causing the bank to lose confidence in the repayment of college students after graduation, and then strictly control the loan or not to lend. So that the students with financial difficulties can not be guaranteed in a timely manner and lose their right to study.

The Lack of Integrity of Employment, Forged Various Types of Honor Certificate. In recent years, with the expansion of college enrollment, making the employment of graduates of the growing pressure. In order to obtain better job opportunities, part of the graduates to make a fuss in the resume, forged academic performance, school reviews, but also forged a variety of honorary certificates [4]. Such as diploma, degree card, certificates of CET-4 or CET-6 and all kinds of honor 
certificates. These fraudulent bad behavior, seriously affected the healthy development of the graduates of the talent market. The emergence of these phenomena, reflecting the integrity of today's college students continue to decline, which will seriously affect their own outlook on life and values.

\section{The Root Cause of the Lack of Integrity}

The Absence of Family Education. Most of the contemporary college students are the only child, are the pearl of the parents.As the parents over doted on their children, there is a phenomenon that the children done the wrong things but reluctant to punish. This leads to their self-centered tendencies is very serious, working only consider their own interests and Convenient and often appear bad faith behavior [5]. According to survey analysis of Qiu yue Guo found that [6], in the establishment of the concept of integrity and the development of the behavior of integrity, the family education played the most important role, reaching 79.96\%. Therefore, the family education plays a vital role in the establishment of integrity, to arouse the parents enough attention.

The Impact of Social Negative Factors. In the real world, the phenomenon of lack of integrity is full of students around, such as the proliferation of fake and shoddy goods, tax evasion, corruption, fraud false advertising everywhere pyramid schemes, network fraud and other phenomena occur frequently, the phenomenon of serious lack of credibility from the community all areas, all levels constantly breeds, spreads, but also penetrates into the daily life of college students, so that college students appear weak feelings in interpersonal relationships, lack of integrity, lack of security, so that college students vacillate and doubt on the traditional concept of morality and integrity of the principle, its seriously affected the effect of honest education in colleges and universities.

The Sense of Responsibility of College Students is Weak. Contemporary college students are accompanied by the establishment of Chinese reform and opening up, the establishment of market economic system and grow up, with strong sense of competition, market awareness and self-awareness, but it is undeniable that there is a weak sense of responsibility in their body. First, the sense of social and historical responsibility is not strong. Some college students are not clear about the historical task to be assumed. They are not clear that they are the pillars of the future modernization of socialism and the hope of national rejuvenation. They can not correctly understand the current complex international and domestic situation, confined to the narrow field of view, and pay attention to personal interests. Followed by a sense of social responsibility is not strong. Part of the students do things with the nature, lack of consideration of the consequences of behavior, there is no clear responsibility for their own actions. When they find their improper behavior, they are not to right face and bear the consequences of their actions, but try to hide, dodge and shirk.

The Foundation of Integrity Education in Colleges and Universities is Weak. School is an important position for moral education, all kinds of schools at all levels must conscientiously implement the party's education policy, comprehensively promote quality education, combine teaching and education together. We should carry out the integrity of education to the students' daily behavior norms, to penetrate into all aspects of school education [7]. Most colleges and universities in our country only have ideological and moral training courses to educate and study, which makes the foundation of integrity education in colleges and universities is weak and the phenomenon of insufficient attention is very common [8].

The Dilution of Traditional Culture Education. The traditional culture of the Chinese nation respects integrity and fulfills its promises, many of which are discussions on integrity. Confucius said: A person if he fails to keep faith, does not know how he was a human. But in the market economy conditions, people on the traditional culture to take a negative attitude, so that the traditional culture suffered a serious blow, the birth of new China lacks some cultural accumulation and mental preparation, so that the Chinese society with the traditional have broke, and in a rootless state [9]. Now the college students are after 90's, in a period of social transformation, during this period, college students did not establish the correct values, the cognitive of integrity can also be 
imagined.

\section{The Countermeasures to Solve the Lack of Integrity}

Play the Model of Family Honesty Education. Parents are the children's first teacher, in order to make children healthy and robust growth, parents must establish their role model from the child in the childhood, as a parent, we must keep principle and promises and do as promised In daily life, to develop a good living habits of children, for the unreasonable demands of children, should not give up their own principles because of the crying of children, over time it will lead to dishonest. In addition, in their children's education, to follow the law of their children's growth, parents should use the correct education method, guide their children to establish a correct view of life and morality, should avoid direct and crude education method, but persuade education, inspired induction.

Strengthen the Integrity of the Campus Education, is the Fundamental of Setting up Moral Education. University is the cradle of cultivating college students, it is the critical period to cultivate college students have a good quality. Therefore, higher education is vital for a college student. For the college education, First, we must pay attention to the status of honesty education in university education. We must integrate honesty education into school moral education system, from entrance education to graduation education, from moral education to professional basic course, specialized course, from daily behavior management to the campus activities, should infiltrate the integrity of education into the college education. Secondly, in the construction of teachers' morality, we must resolutely put an end to the occurrence of academic misconduct, in the management of students, each teacher must perform their duties, dutifully. Combined with the new form of education, the teacher should innovative forms of integrity education to reach resonance of students in the emotional, using new media, microblogging blog and other forms. Paying Attention to the education of honesty and behavior of Senior Students to apply for a job, improvement of students' cognitive of integrity in the ideological, so as to enhance the level of personal integrity morality, to form integrity behavior [10].

Create Personal Integrity File. For colleges and universities, it should combine the students' learning performance and life performance with scholarships, selection, grants and join the party and so on, improve the management and update of the integrity file. At the same time to formulate the evaluation criteria, according to three evaluation, individual, class and counselor, to update each semester, the evaluation results will be added to the student's personal files, increase the punish power of students' dishonesty behavior [11]. So that students understand with a high degree the important role of integrity and morality in ideology and behavior, to promote students to unify knowledge and practice, to avoid deviation between knowledge and practice. And the establishment of the national network of integrity education system. And the bad credit records, dishonesty, cheating should be subject to school rules and moral condemnation, legal sanctions. In short, through daily education to encourage integrity, punish the dishonesty, effectively resist the occurrence of dishonesty and the other moral behaviors.

To Build a Integrity Education System of the School, Society and Family Combination. The status of the school in the social system and its basic nature determines that the school education is irreplaceable, the moral education to school as the main carrier has the strongest controllability, and it has the dominant status in the moral education process[12].Therefore, we should take the school education as the leading, at the same time, we should take the social and family factors into the integrity of the school education process, to give full play to the function of integration impact to the development of college students' integration quality, in order to form a concerted effort of combined action on the development of college students. 


\section{References}

[1] J Xie, A Study on the Status of Honesty and the Construction of Credit System of College Students[J]. Journal of Taiyuan Urban Vocational and Technical College.2014,07: 55-56(In Chinese).

[2] G.L Zhou and J hen, Analysis on the Motivation of College Students' Examination Fraud and Its Countermeasures[J]. Journal of Heilongjiang College of Education.Vol.32 (2013) No.11, p.121-124. (In Chinese).

[3] G.J Zheng, Honesty Education is the Choice of Flexible System for the Construction of Credit Guarantee System of Student Loan in China[J]. Journal of Chifeng University, Vol. 27 (2011) No. 1, p.163-166(In Chinese).

[4] Y He, An analysis of construction of college students integrity system[J].School Party Building and Ideological Education,2012,No. 10, P.32-34 (In Chinese).

[5] T.M Wang, An analysis of the status and causes of credit lack of contemporary college students[J]. Journal of Southwest University for Nationalities,2012,No. 4,P. 173-175(In Chinese).

[6] Q.Y Guo, Study on the current situation of college students' credit and the way of education [J]. Journal of Xichang College. Natural Science Editio, 2013, Vol.27, NO.4,P.86-89(In Chinese).

[7] D.Y Xia, X.S.Zuo and X.H.Zuo. The importance of credit education in contemporary college students[J].Journal of Taiyuan University,Vol.32(2014) No.1,P.81-84(In Chinese).

[8] Z.H Zhao, A study on the integrity education of college students[D]. Jinzhong: Shanxi Agricultural University, 2013(In Chinese).

[9] J Mao and X.R Chen, A perspective of college students' lack of honesty in the context of socialist core values[J].Education Teaching Forum, 2015, NO.11, p.78-78(In Chinese).

[10]Z.R Cai, An analysis of lack of integrity of college students and the reconstruction measures of integrity[J]. Ideological and Political Education .2014, No.1,P.29,37(In Chinese).

[11]Q Cheng, Integrity education of college students [J]. Journal of Hubei Science and Technology University, Vol.34 (2014) No. 7,P.147-148. (In Chinese).

[12]X.G Yu and Y.H Zhang, Analysis of Current Situation and educational countermeasures of integrity of college students[J].Journal of Shandong Youth Administrative Cadres College,2007,No.2, p.54-56(In Chinese). 